\title{
OPTIMASI PROSES EKSTRAKSI BAHAN-BAHAN MINUMAN TRADISIONAL INDONESIA
}

\author{
(Optimization of Extraction Process from Indonesian Traditional Drink \\ Ingredients)
}

\author{
Yunita Siti Mardhiyyah $^{\mathrm{a} *}$, Budi Nurtama $^{\mathrm{b}}$, C. Hanny Wijaya ${ }^{\mathrm{b}}$ \\ ${ }^{a}$ Departemen Teknologi Industri Pertanian, Universitas Internasional Semen Indonesia, Gresik, Indonesia \\ ${ }^{b}$ Departemen IImu dan Teknologi Pangan, Fakultas Teknologi Industri Pertanian, Institut Pertanian Bogor, \\ Bogor, Indonesia \\ * Penuliskorespondensi \\ Email: yunita.mardhiyyah@uisi.ac.id
}

\begin{abstract}
Indonesia is known for its local wisdom with functional food potential in the form of traditional drinks. Traditional drinks products are made from the extraction of natural ingredients such as ginger and turmeric rhizome, java tea leaves, and sappan wood. The functional health of functional drinks is influenced by the effectiveness of phytochemical components extraction from ingredients. The purpose of this study was to obtain the optimal extraction process from traditional Indonesian beverage ingredients, namely java tea, sappan, ginger and turmeric. Optimizing the extraction time of java tea leaves and sappan wood was developed using Response Surface Methodology with Design Expert 7.0 software. The optimum extraction process from java tea leaves and sappan wood is obtained by heating in water for 30 minutes with ratio of ingredients and water was 1:25. Mathematical equations can be used to predict total phenol and antioxidant extract activity. Scaling up caused a decrease in antioxidant activity and total phenol of extracts. On the pilot plant scale the value of antioxidant activity and total phenol were 2508.9 ppm AEAC and 926.6 ppm GAE for java tea leaves extracts and for sappan wood extract were 1601.7 ppm AEAC and 1319.9 ppm GAE. The efficiency and effectiveness of the ginger extraction process was obtained through soaking the rhizome in hot water $\left(90-95^{\circ} \mathrm{C}\right)$ for 3 minutes, while turmeric did not need to be carried out. Extraction of ginger by this way was able to provide total phenol of $2294.6 \mathrm{ppm}$ GAE and $61.1 \%$ yield. The optimum extraction procedure in turmeric gave a total phenol extract of $5621.8 \mathrm{ppm}$ GAE and a yield of 46.9\%. Thus, the optimum extract obtained can be used for functional drink formulations with various health benefits.
\end{abstract}

Keywords: extraction, phenol, antioxidant, java tea, sappan, ginger, turmeric

\begin{abstract}
ABSTRAK
Indonesia dikenal akan kearifan lokal dengan potensi pangan fungsional berupa minuman-minuman tradisional.Produk minuman tradisional dibuat dari ekstraksi bahan alami seperti rimpang jahe dan temulawak, daun tanaman kumis kucing, serta kayu secang.Kemampuan bioaktif minuman salah satunya dipengaruhi oleh efektivitas ekstraksi komponen fitokimia dari bahan-bahan minuman.Tujuan penelitian ini adalah mendapatkan proses ekstraksi yang optimal dari bahan-bahan minuman tradisional Indonesia, yaitu kumis kucing, secang, jahe dan temulawak. Optimasi waktu ekstraksi daun tanaman kumis kucing dan kayu secang dikembangkan menggunakan Response Surface Methodology dengan software Design Expert 7,0. Proses ekstraksi optimum dari daun tanaman kumis kucing dan kayu secang didapatkan selama 30 menit pemanasan dalam air dengan perbandingan bahan dan air 1:25. Persamaan matematika dapat digunakan untuk memprediksi total fenol dan aktivitas antioksidan ekstrak. Peningkatan skala menyebabkan penurunan aktivitas antioksidan dan total fenol pada ekstrak daun
\end{abstract}


tanaman kumis kucing dan kayu secang. Pada skala pilot plant nilai aktivitas antioksidan 2508,9 ppm AEAC dan total fenol 926,6 ppm GAE untuk ekstrak kumis kucing dan nilai aktivitas antioksidan 1601,7 ppm AEAC dan total fenol 1319,9 ppm GAE untuk ekstrak kayu secang. Efisiensi dan efektivitas proses ekstraksi jahe diperoleh melalui pemblansiran dengan direndam air panas $\left(90-95^{\circ} \mathrm{C}\right)$ selama 3 menit, sedangkan temulawak tidak perlu dilakukan pemblansiran. Ekstraksi jahe dengan cara tersebut mampu memberikan total fenol 2294,6 ppm GAE dan rendemen 61,1\%. Prosedur ekstraksi optimum pada temulawak memberikan total fenol ekstrak 5621,8 ppm GAE dan rendemen 46,9\%. Ekstrak optimum yang didapatkan dapat digunakan untuk formulasi minuman fungsional dengan berbagai manfaat bagi kesehatan.

Kata kunci: ekstraksi, fenol, antioksidan, tanaman kumis kucing, secang, jahe, temulawak

\section{PENDAHULUAN}

Tren pangan fungsional atau pangan yang bermanfaat bagi kesehatan saat ini semakin marak di masyarakat Indonesia. Isu back to nature dan kesadaran akan local wisdom menyebabkan semakin banyak produk berklaim pangan fungsionaldikembangkan dan diproduksi yang berasal dari bahan lokal. Indonesia dikenal akan kearifan lokal yang tinggi memiliki potensi pangan fungsional berupa minuman-minuman tradisional.Minuman tradisional di Indonesia sangat beragam dan hampir setiap daerah memiliki jenis minuman tradisional. Contoh produk minuman tradisional seperti wedang jahe, bajigur, sinom, kunyit asem,wedang pokak dan lain-lain (Septiana et al. 2017). Produk minuman tradisional ini dibuat dari ekstraksi bahan-bahan alami seperti rimpang (jahe, temulawak, kunir, dll), daun (kumis kucing, sambiloto, dII), batang (secang, kayu manis, dII) dan juga dari buah (lemon, jeruk nipis, jeruk limau, dll).

Tingginya antusiasme konsumen Indonesia terhadap minuman yang memiliki manfaat kesehatan atau minuman fungsional, mendorong peneliti mengembangkan berbagai jenis minuman fungsional baru yang berbasis bahan alami khas Indonesia. Wijaya et al. (2011) mengembang minuman fungsional berbasisdaun tanaman kumis kucing (Orthosiphon aristatus BI. Miq) yang memiliki aktivitas antioksidan dan antihiperglikemik. Septiana et al. (2017) bahkan mengembangkan berbagai minuman tradisional Indonesia dengan penambahan rempah-rempah lainnya. Minuman fungsional yang dikembangkan peneliti untuk memberikan manfaat kesehatan berupa kemampuan atioksidan (Defang et al. 2015, Suratno et al. 2014), antihiperglikemik (Rekasih 2016), dan lainlain. Di antara berbagai jenis rempah dan tanaman yang berkhasiat kesehatan, daun tanaman kumis kucing, kulit kayu secang, rimpang jahe dan rimpang temulawak dipilih dalam penelitian ini karena banyak digunakan dalam beberapa minuman tradisional Indonesia dan formulasi minuman fungsional serta memiliki manfaat kesehatan.

Efektivitas manfaat kesehatan dari minuman fungsional akan optimal jika komponen bioaktif yang berperan dapat terekstrak dengan baik dari bahan baku atau rempah yang digunakan. Selain kualitas bahan baku, proses ekstraksi yang tepat menjadi faktor yang sangat mempengaruhi mutu produk minuman yang dihasilkan.Kemampuan bioaktif minuman dipengaruhi oleh beberapa faktor, yaitu efektivitas ekstraksi komponen fitokimia dari bahan-bahan minuman, proses pengolahan minuman (pemanasan dan pasteurisasi) serta kondisi penyimpanan. Veljovic et al. (2015) menyatakan bahwa waktu ekstraksi dan suhu sangat berpengaruh terhadap komponen bioaktif yang terkestrak. 
Proses ekstraksi komponen bioaktif dari bahan baku minuman atau rempah dilakukan melalui berbagai cara. Secara konvensional, metode ekstraksi yang digunakan adalah maserasi dan dengan pelarut (ditambah dengan pemberian panas). Adapun metode lain yang telah banyak digunakan untuk ekstraksi dengan gelombang ultrasonic, gelombang microwave, pulsed electric field serta supercritical fluida (Hidalgo and Almajano 2017). Walaupun metode maserasi dan ekstraksi pelarut memiliki banyak kekurangan karena membutuhkan waktu yang lama ataupun rendemen komponen bioaktifnya yang rendah, tetapi metode tersebut paling umum digunakan dalam proses pembuatan minuman fungsional dalam skala kecil/tradisional. Secara umum dan sederhana pembuatan minuman tradisional berbasis rempah dilakukan dengan perebusan semua bahan menjadi satu dalam panci besar, kemudian dilakukan proses penyaringan dan pengemasan. Proses pengolahan bahan panganharus mudah diterapkan, efisien dan efektif. Cara ini tergolong cepat namun kurang efektif dalam mengkekstrak komponen bioaktif dari bahan baku.Agar didapatkan ekstrak dengan kandungan komponen bioaktif yang optimum dari masing-masing bahan, maka perlu dilakukan proses ekstraksi secara terpisah. Oleh karena itu, tujuan dari penelitian ini adalah mendapatkan proses ekstraksi yang optimal dari bahan-bahan minuman tradisional Indonesia, yaitu kumis kucing, secang, jahe dan temulawak.

\section{BAHAN DAN METODE}

\section{Bahan}

Bahan-bahanminuman tradisional yang diteliti terdiri atas daun tanaman kumis kucing segar (dipetik pagi hari, dipilih daun yang muda) dari kebun Pusat Studi Biofarmaka IPB Cikabayan-Dramaga, jahe gajah segar, temulawak segar, dan kayu secang kering (rautan) yang diperoleh dari pasar Bogor. Bahan analisis sampel terdiri atas Folin Ciocalcetau (Sigma 47641),
$\mathrm{Na}_{2} \mathrm{CO}_{3}$, asam askorbat, asam galat, 2,2Diphenyl-1-picrylhydrazyl atau DPPH (Sigma 43180), metanol p.a, dan akuades.

\section{Alat}

Alat yang digunakan adalah spektrofotometer, termometer, rotavapor, oven pengering, hot plate, timbangan, parutan, kain saring, dan alat-alat gelas.

\section{Tahapan Penelitian}

Proses ekstraksi (dijelaskan pada sub bab berikutnya) dari daun tanaman kumis kucing dan kayu secang yang dipilih adalah melalui perebusan (solvent extraction) dalam air panas. Adapun pada jahe dan temulawak metode ekstraksi dilakukan dengan penghancuran dan penyaringan.

\section{Optimasi Ekstraksi Daun Tanaman Kumis Kucing dan Kayu Secang}

Proses ekstraksi daun tanaman kumis kucing dan kayu secang terdiri atas beberapa tahapan meliputi pencucian, pemblansiran, ekstraksi (perebusan), pemekatan (evaporasi) dan pasteurisasi ekstrak. Fokus penelitian pada tahap ini adalah pengaruh waktu ekstraksi terhadap total fenol dan aktivitas antioksidan. Pada ekstraksi daun tanaman kumis kucing, waktu ekstraksi yang diamati ialah 10, 15, 20, 23, 25, 30, 33, 37, 42, 46, dan 50 menit. Pada secang waktu ekstraksi yang diamati ialah 5, 10, 15, 20, 25, 30, 35, 40, 45, 50, 55 dan 60 menit.

Daun tanaman kumis kucing segar dicuci, kemudian ditiriskan. Daun tersebut dimasukkan dalam kantong yang terbuat dari kain saring dengan ukuran pori-pori 100 Mesh dan kantong ditutup/diikat. Air kemudian dipanaskan sampai suhu $\pm 95^{\circ} \mathrm{C}$. Kantong yang berisi daun tanaman kumis kucing dimasukkan ke dalam air dan dipertahankan suhu air pada rentang 90$95^{\circ} \mathrm{C}$. Waktu ekstraksi mulai dihitung saat daun tanaman kumis kucing dimasukkan. Pada titik-titik waktu tertentu, seperti pada paparan di atas, dilakukan pengambilan sampel air hasil rebusan (ekstrak) sejumlah 5-10 ml untuk dianalisis total fenol dan 
aktivitas antioksidan. Prosedur kerja ini juga berlaku proses esktraksi kayu secang.

Optimasi ekstraksi daun tanaman kumis kucing dan kayu secang didasarkan pada aktivitas antioksidan dan total fenol yang tinggi pada ekstrak dengan perkiraan biaya yang rendah. Pengolahan data untuk optimasi menggunakan DX $7^{\circledR}$ pada metode Response Surface Methodology-Historical Data. Waktu optimum terpilih akan diverifikasi berdasarkan total fenol ekstrak. Percobaan verifikasi dilakukan dua kali ulangan dengan analisis duplo.

\section{Optimasi Ekstraksi Jahe dan Temulawak}

Proses ekstraksi jahe dan temulawak terdiri atas pembersihan, pemblansiran, pengecilan ukuran (pemarutan), ekstraksi (pemerasan), pengendapan/dekantasi, dan pasteurisasi. Rimpang jahe dan temulawak segar dibersihkan dengan cara disikat dan dibilas dengan air mengalir. Rimpang diberi perlakuan blansir kemudian diparut mengggunakan papan parutan. Hasil parutan rimpang dimasukkan dalam kain saring dan diperas. Cairan hasil perasan dibiarkan selama semalam ( \pm 18 jam) untuk mengendapkan partikel tidak larut air (seperti pati) agar minuman terlihat lebih jernih. Pemisahan cairan dan endapan ekstrak jahe dan temulawak dilakukan dengan penuangan secara perlahan ke dalam wadah lainnya. Cairan yang diambil kemudian dimasukkan dalam botol kaca gelap dan dipasteurisasi pada suhu $75^{\circ} \mathrm{C}$ selama 30 menit.

Tahapan proses yang menjadi fokus penelitian adalah pemblansiran. Penilaian perlakuan pemblansiran dilakukan dengan metode pembobotan. Parameter yang diamati ialah rendemen ekstraksi dan total fenol ekstrak. Pengujian kadar air jahe dan temulawak juga dilakukan. Jenis perlakuan yang diujikan pada ekstraksi jahe dan temulawak terdiri atas 7 perlakuan yaitu:

1. Ekstraksi langsung tanpa pemblansiran

2. Ekstraksi dengan adanya pemblansiran dalam air panas atau direbus (Febriani 2012)
3. Ekstraksi dengan adanya pemblansiran dengan air panas (disiram)

4. Ekstraksi langsung tanpa pemblansiran dengan penambahan air $1: 1$

5. Ekstraksi langsung tanpa pemblansiran dengan penambahan air 1:2

6. Ekstraksi langsung tanpa pemblansiran dengan penambahan air 1:3

7. Ekstraksi langsung tanpa pemblansiran dengan penambahan air 1:4

\section{Analisis Total Fenol (modifikasi Strycharz dan Shetty 2002)}

Pengukuran total fenol dilakukan metode Folin-Ciocalcetau dengan asam galat sebagai standar. Analisis dimulai dengan melarutkan $1 \mathrm{ml}$ larutan standar atau sampel ke dalam $5 \mathrm{ml}$ air suling dan $0,5 \mathrm{ml}$ larutan reagen. Larutan kemudian diinkubasi selama 5 menit dalam ruang gelap kemudian ditambahkan $1 \mathrm{ml}$ larutan $\mathrm{Na}_{2} \mathrm{CO}_{3}$ dan diinkubasi kembali dalam ruang gelap selama 1 jam. Setelah inkubasi, larutan divorteks dan diukur absorbansinya dengan spektrofotometer pada panjang gelombang $725 \mathrm{~nm}$. Blanko spktrofotomer ialah akuades. Pada analisis total fenol ekstrak, sampel ekstrak diambil langsung dari stok dan dilakukan pengenceran. Pengujian fenol pada sampel dilakukan pada hari yang sama dengan hari pembuatan sampel.

\section{Analisis Aktivitas Antioksidan (Molyneux 2004)}

Pengukuran aktivitas antioksidan ekstrak dilakukan dengan metode penghambatan radikal bebas DPPH (1,1diphenyl-2-picrylhydrazil radicalscavenging). DPPH sebagai radikal akan bereaksi dengan hidrogen (yang bersal dari antioksidan) dan membentuk DPPH tereduksi yang berwarna kuning dan dapat terukur dengan spektrofotometri sinar tampak.Asam askorbat digunakan sebagai standar pembanding aktivitas antioksidan sampel. Aktivitas antioksidan minuman dihitung berdasarkan kesetaraannya dengan aktivitas antioksidan asam askorbat 
yang dinyatakan dalam ppm AEAC (Ascorbic Acid Equivalent Antioxidant Capacity).

Tahap analisis dimulai dengan mencampurkan $2 \mathrm{ml}$ larutan buffer asetat $(\mathrm{pH} \mathrm{5,5}), 3,75 \mathrm{ml}$ methanol dengan $200 \mu \mathrm{l}$ larutan DPPH $3 \mathrm{mM}$ dalam methanol, kemudian di-vorteks. Larutan campuran ditambahkan 50 $\mathrm{\mu l}$ larutan sampel atau larutan standar antioksidan. Larutan kemudian di-inkubasi pada suhu $37^{\circ} \mathrm{C}$ menggunakan waterbathselama 30 menit. Absorbansi larutan kemudian diukur dengan spektrofotometer pada $\lambda=517 \mathrm{~nm}$. Blanko spektrofotometer ialah akuades.

Response Surface Methodology (RSM) untuk Optimasi Ekstraksi Daun Tanaman Kumis Kucing dan Kayu Secang

Optimasi dilakukan dengan RSM menggunakan software Design Expert (DX) 7. DX 7 mengolah rangkaian data respon yang ada menjadi suatu model atau persamaaan. Model yang diterapakan pada program DX 7 merupakan model-model polinomial yang terdiri dari mean, linier, kuadratik, dan kubik. Penentuan model didasarkan pada pemilihan model dengan orde paling tinggi yang memiliki nilai signifikansi paling kecil (nilai-P kecil), tidak ada lack of fit (nilai $p>0,10$ ), dan memiliki nilai adjusted $R$-square dan predicted $R$ square yang hampir sama (minimal berjarak 0,2) (Stat Ease 2005).

Model-model dari setiap respon dioptimasi dengan kondisi perlakuan yang diinginkan. Kondisi perlakuan yang diinginkan ialah waktu target 30 menit dengan nilai kepentingan 3 , total fenol maksimal dengan nilai kepentingan 5, aktivitas antioksidan maksimal dengan nilai kepentingan 3 , dan biaya minimal dengan nilai kepentingan 3. Nilai waktu hasil optimasi berdasarkan kondisi yang ditentukan, akan ditampilkan oleh program dengan memberikan nilai kepuasan (desirability) dalam memenuhi kriteria yang ditetapakan. Perlakuan waktu ekstraksi yang memiliki nilai desirability paling tinggi akan digunakan sebagai acuan proses ekstraksi.

\section{Pembobotan, One-way ANOVA dan Uji Lanjut Duncan pada Ekstraksi Jahe dan Temulawak}

Total fenol dan rendemen untuk masing-masing perlakuan pada esktraksi jahe dan temulawak diberikan nilai (1-7) berdasarkan rentang tertentu. Total fenol memberikan kontribusi nilai sebesar 60\% dan rendemen sebesar $40 \%$. Total fenol memiliki prioritas lebih tinggi karena minuman dibuat dengan tujuan memiliki keunggulan antivitas antioksidan dan antihiperglikemik. Hasil penilaian pembobotan masing-masing perlakuan dianalisis menggunakan metode One-Way ANOVA dengan program IBM SPSS versi 20 untuk mengetahui pengaruh perlakuan terhadap parameter yang diukur. Ada tidaknya perbedaan antara rerata parameter yang diukur diketahui dengan melakukan uji lanjut Duncan.

\section{Analisis Statistik}

Data pada penelitian ini dilaporkan dalam bentuk rata-rata \pm standar deviasi dan grafik yang diolah dengan Microsoft Excel. Perbedaan antar perlakuan dianalisis dengan uji lanjut DMRT (Duncan). Analisis statistik dilakukan dengan SPSS versi 20.

\section{HASIL DAN PEMBAHASAN}

\section{Optimasi ekstraksi daun tanaman kumis kucing}

Bahan minuman fungsional diekstraksi sesuai dengan prosedur ekstraksi masing-masing. Bahan daun tanaman kumis kucing dan kayu secang dioptimasi proses ekstraksinya berdasarkan lama waktu ekstraksi atau perebusan dalam air mendidih pada dua kondisi yang berbeda yaitu skala laboratorium (1 liter) dan skala pilot plant (50 liter). Kedua proses ekstraksi menggunakan perbandingan bahan dan air $1: 25$.

Pengujian ekstraksi daun tanaman kumis kucing pada skala pilot plant memberikan hasil total fenol yang berbeda 


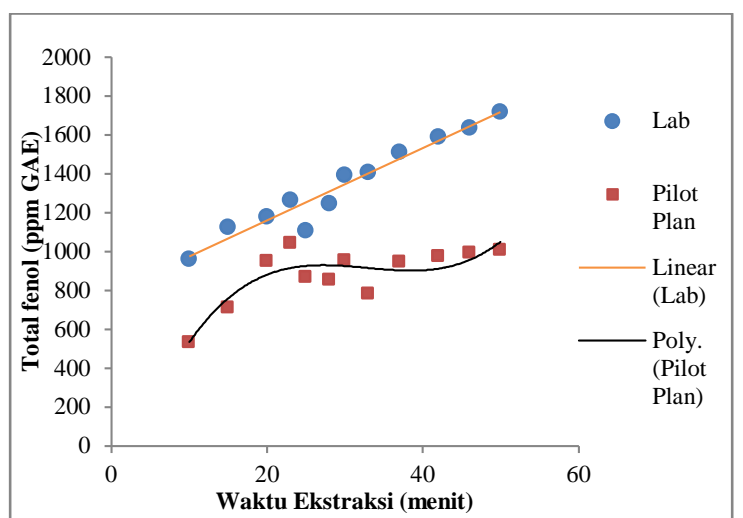

(a)

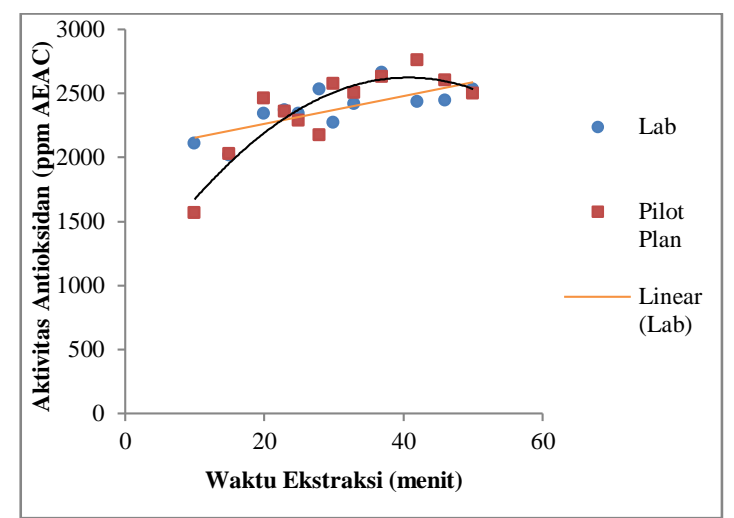

(b)

Gambar 1. Kurva perbandingan total fenol (a) dan aktivitas antioksidan (b) ekstrak daun tanaman kumis kucing pada skala laboratorium dan pilot plant

Tabel 1. Persamaan matematika total fenol dan aktivitas antioksidan pada ekstrak daun tanaman kumis kucing terhadap waktu ekstraksi

\begin{tabular}{llll}
\hline No & $\begin{array}{c}\text { Komponen } \\
\text { bioaktif }\end{array}$ & \multicolumn{1}{c}{$\begin{array}{c}\text { Skala } \\
\text { ekstraksi }\end{array}$} & \multicolumn{1}{c}{ Persamaan matematika } \\
\hline 1 & Total fenol & Laboratorium & $+786,90+\left(18,58^{*}\right.$ Waktu $)$ \\
& & Pilot plant & $-351,83+\left(123,47^{*}\right.$ Waktu $)-\left(3,88^{*}\right.$ Waktu $\left.^{2}\right)+\left(0,04^{*}\right.$ Waktu $\left.^{3}\right)$ \\
2 & Aktivitas & Laboratorium & $+2044,479+\left(10,88^{*}\right.$ Waktu $)$ \\
& antioksidan & Pilot plant & $+951,79+\left(82,21^{*}\right.$ Waktu $)-1,01^{*}$ Waktu $^{2}$ \\
\hline
\end{tabular}

signifikan dengan hasil di laboratorium (Gambar 1a), adapun pada hasil aktivitas antioksidan tidak menunjukkan perbedaan yang signifikan antara skala laboratorium dan pilot plantseperti pada Gambar $1 b$. Perbedaan skala produksi memungkinkan perbedaan komponen bioaktif yang terekstrak, baik dari segi jumlah ataupun jenis komponen bioaktif. Total fenol yang tinggi tidak selalu dihubungkan dengan aktivitas antioksidan yang juga tinggi. Sithisarn \& Jarikasem (2010) menunjukkan bahwa komponen fenolik yang tinggi pada Acanthopanax trifoliatus and Toddalia asiatica tidak menunjukkan aktivitas antioksidan yang tinggi dengan metode analisis DPPH. Aktivitas antioksidan pada tanaman juga dipengaruhi oleh beberapa komponen lain, seperti asam askorbat, karetenoid, tokferol, klorofil, dan juga komponen pengkelat logam (Takamatsu et al. 2003, Chanwitheesuk et al. 2005).
Gambar 1 menunjukkan bahwa semakin lama waktu ekstraksi daun tanaman kumis kucing pada skala laboratorium, maka total fenol dan aktivitas antioksidannya juga cenderung meningkat. Total fenol dan aktivitas antioksidan hasil ekstraksi skala pilot plant cenderung mencapai titik puncak dan menurun.Proses esktraksi komponen fenol pada daun tanaman kumis kucing terjadi pada setiap kenaikan waktu proses, tetapi kemungkinan adanya degradasi termal terhadap komponen fenolik selama pemanasan juga menjadi penyebab nilai total fenol ekstrak yang tetap. Sensitivitas komponen fenolik terhadap kerusakan termal (oksidasi) ataupun kerusakan aktivitas dapat terjadi pada pemanasan dengan suhu dan waktu tertentu (Lafka et al. 2007). Qu et al. (2010) menunjukkan bahwa peningkatan waktu ekstraksi akan meningkatkan total fenol pada ekstrak air bahan, namun pada waktu 
tertentu akan terjadi titik kejenuhan total fenol ekstrak. Silva et al. (2007) menambahkan bahwa Hukum Kedua Fick tentang difusi menyatakan bahwa titik keseimbangan akhir pada konsentrasi larutan dari matriks padat atau dari larutan yang meruah akan dicapai setelah periode waktu tertentu.

Pemodelan fungsi total fenol dan aktivitas antioksidan didapatkan menggunakan Design Expert ${ }^{\circledR} 7$ seperti pada Tabel 1. Persamaan tersebut selanjutnya dapat dipakai untuk memprediksi kandungan total fenol dan aktivitas antioksidan ekstrak, jika dilakukan ekstraksi pada waktu yang berbeda.

Data yang didapatkan kemudian diolah menggunakan Design Expert?, maka diperoleh waktu optimum untuk ekstraksi daun tanaman kumis kucing pada skala laboratorium ialah 33 menit dengan nilai aktivitas antioksidan 2406,2 ppm AEAC dan total fenol 1404,9 ppm GAE. Pada skala pilot plantdidapatkan waktu optimum 30 menit dengan nilai aktivitas antioksidan 2508,9 ppm AEAC dan total fenol 926,6 ppm GAE. Oleh karena itu, ekstraksi daun tanaman kumis kucing optimum pada kondisi pemanasan air pada suhu $\pm 95^{\circ} \mathrm{C}$ selama 30 menit.

\section{Optimasi ekstraksi kayu secang}

Pengujian ekstraksi kayu secang pada skala pilot plant memberikan hasil total fenol dan aktivitas antioksidan yang berbeda dengan hasil di laboratorium (Gambar 2). Kondisi pilot plantmemberikan hasil yang rendah daripada hasil di laboratorium dan memerlukan penyesuaian terlebih dahulu. Pada skala pilot plant, jumlah bahan yang diekstrak cukup banyak dan ukuran tangki ekstraktor juga besar (100 liter). Hal tersebut menyebabkan penetrasi air menjadi berkurang dan dispersi panas tidak merata. Kondisi ini menyebabkan ekstraksi tidak berlangsung optimal dan memberikan hasil ekstraksi yang rendah pada indikator total fenol dan aktivitas antioksidan.Bousetta et al. (2012) menyatakan bahwa pada hasil ekstraksi komponen fenol dari grape-pomace pada skala pilot plant lebih rendah daripada hasil yang diperoleh pada skala laboratorium. Proses pemekatan (evaporasi) merupakan salat satu cara yang dapat dilakukan untuk meningkatkan kualitas ekstrak pada skala pilot plant. Didapatkan pula korelasi positif total fenol dan aktivitas antioksidan pada ekstrak kayu secang. Bettuzzi (2009) menyatakan bahwa senyawa dari golongan polifenol memiliki aktivitas antioksidan yang sangat kuat.

Pemodelan fungsi total fenol dan aktivitas antioksidan didapatkan menggunakanDesign Expert ${ }^{\circledR} 7$ seperti pada Tabel 2. Persamaan tersebut selanjutnya dapat dipakai untuk memprediksi kandungan total fenol dan aktivitas antioksidan ekstrak, jika dilakukan ekstraksi pada waktu yang berbeda.

Data yang didapatkan kemudian dioptimasimenggunakanDesign Expert ${ }^{\circledR}$, maka diperoleh waktu optimum untuk ekstraksi kayu secang pada skala laboratorium ialah 34 menitdengan nilai aktivitas antioksidan 3523,7 ppm AEAC dan total fenol 2131,2 ppm GAE. Pada skala pilot plant didapatkan waktu optimum 30 menit dengan nilai aktivitas antioksidan 1601,7 ppm AEAC dan total fenol 1319,9 ppm GAE. Oleh karena itu, ekstraksi kayu secang kucing optimum pada kondisi pemanasan air pada suhu $\pm 95^{\circ} \mathrm{C}$ selama 30 menit

\section{Ekstraksi Jahe}

Pada proses ekstraksi jahe, kendala yang dihadapi pada pembuatan ekstrak jahe yaitu rendahnya rendemen yang dihasilkan. Beberapa penelitian menujukkan bahwa ekstraksi jahe segar mendapatkan rendemen pada kisaran 52-58\% (Herold,2005; Indariani 2011). Optimasi proses ekstraksi jahe bertujuan untuk mendapatkan ekstrak dengan rendemen dan nilai fungsional yang tinggi. Nilai fungsional ekstrak jahe diukur menggunakan analisis total fenol. Terdapat tujuh perlakuan blansir yang diujikan. Setiap perlakuan dianalisis jumlah total fenol dan rendemen ekstrak. Hasil total fenol ekstrak dan rendemen dapat dilihat pada Gambar 3. 
Ekstrak jahe yang digunakan dalam minuman ini diperoleh dari hasil pemerasan langsung rimpang jahe sehingga dapat disebut sebagai sari jahe. Vernin \& Parkanyi (2005) menyatakan terdapat dua jenis

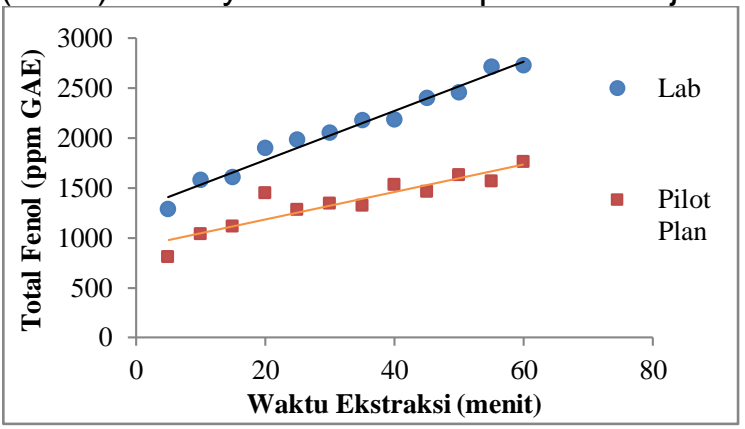

(a) produk dari rimpang jahe, yaitu komponen volatil yang membentuk essensial oil dan komponen non-volatil. Komponen nonvolatil ini meliputi olesorseins (gingerol,

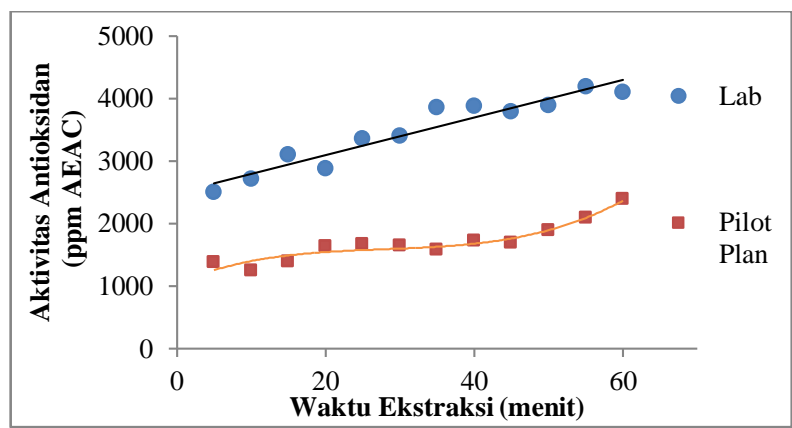

(b)

Gambar 2. Kurva perbandingan total fenol (a) dan aktivitas antioksidan (b) ekstrak kayu secang pada skala laboratorium dan pilot plant

Tabel 2. Persamaan matematika total fenol dan aktivitas antioksidan pada ekstrak kayu secang terhadap waktu ekstraksi

\begin{tabular}{ccll}
\hline No & Komponen bioaktif & Skala ekstraksi & \multicolumn{1}{c}{ Persamaan matematika } \\
\hline 1 & Total fenol & Laboratorium & $+1285,91+\left(24,63^{*}\right.$ Waktu $)$ \\
& & Pilot plant & $+905,48+\left(13,81^{*}\right.$ Waktu $)$ \\
2 & \multirow{3}{*}{ Aktivitas antioksidan } & Laboratorium & $+2493,79+\left(30,01^{*}\right.$ Waktu $)$ \\
& & Pilot plant & $+1050,32+\left(+49,25^{*}\right.$ Waktu $)$ \\
\hline
\end{tabular}

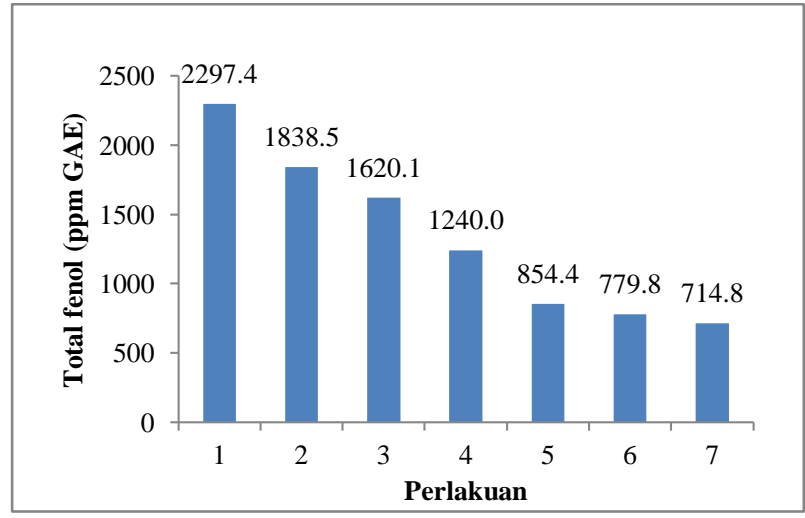

(a)

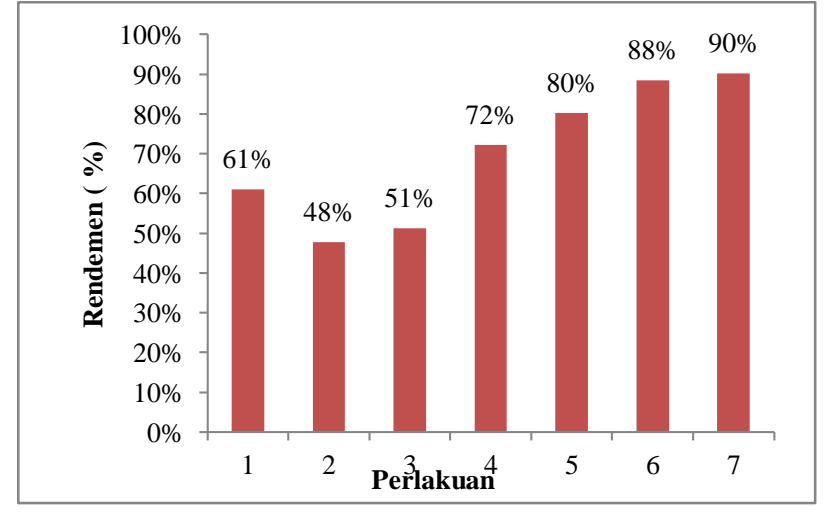

(b)

Keterangan:

Perlakuan 1: diblansir dengan air panas

Perlakuan 2: diblansir dengan didihkan

Perlakuan 3: langsung diekstrak tanpa pengenceran

Perlakuan 4: langsung diekstrak dengan Pengenceran 1:1

Perlakuan 5: langsung diekstrak dengan Pengenceran 1:2

Perlakuan 6: langsung diekstrak dengan Pengenceran 1:3

Perlakuan 7: langsung diekstrak dengan Pengenceran 1:4

Gambar 31. Total fenol (a) dan rendemen (b) ekstrak jahe pada berbagai perlakuan pemblansiran 
Tabel 31. Hasil pembobotan total fenol dan rendemen pada berbagai perlakuan jahe

\begin{tabular}{clllll}
\hline \multirow{2}{*}{ Perlakuan } & \multirow{2}{*}{$\begin{array}{c}\text { Total Fenol (ppm GAE) } \\
(\%)\end{array}$} & \multicolumn{3}{c}{ Nilai } \\
\cline { 4 - 5 } & & $61,1 \%$ & 6,5 & 3 & $\mathbf{5 , 1}^{\mathrm{a}}$ \\
\cline { 4 - 5 } & 2294,6 & $47,8 \%$ & 5 & 1 & $3,4^{\mathrm{b}}$ \\
3 & 1835,8 & $51,3 \%$ & 4 & 1 & $2,8^{\mathrm{b}}$ \\
4 & 1617,4 & $72,2 \%$ & 2,5 & 4,5 & $3,3^{\mathrm{b}}$ \\
5 & 1237,3 & $80,3 \%$ & 1 & 5,5 & $2,8^{\mathrm{b}}$ \\
6 & 851,7 & $88,4 \%$ & 1 & 7 & $3,4^{\mathrm{b}}$ \\
7 & 777,0 & $90,2 \%$ & 1 & 7 & $3,4^{\mathrm{b}}$ \\
\hline
\end{tabular}

Keterangan:

Huruf yang sama dalam satu kolom menyatakan tidak berbeda nyata pada taraf kepercayaan 95\%

Perlakuan 1: diblansir dengan air panas

Perlakuan 2: diblansir dengan didihkan

Perlakuan 3: langsung diekstrak tanpa pengenceran

Perlakuan 4: langsung diekstrak dengan Pengenceran 1:1

Perlakuan 5: langsung diekstrak dengan Pengenceran 1:2

Perlakuan 6: langsung diekstrak dengan Pengenceran 1:3

Perlakuan 7: langsung diekstrak dengan Pengenceran 1:4

shagaol dan komponen pungen lainnya), komponen organik (vitamin) dan juga komponen inorganik (mineral). Ekstrak jahe yang digunakan sebagai bahan minuman fungsional ini merupakan jenis komponen yang larut air, sehingga sangat dipengaruhi oleh kadar air rimpang jahe. Agar didapatkan sari jahe dalam jumlah banyak, maka harus digunakan jahe dengan kadar air yang tinggi yaitu $80-90 \%$ atau dalam keadaan segar. Pada penelitian ini, kadar air jahe yang digunakan yaitu 84,72\% (bb).

Berdasarkan Gambar 3, perlakuan ekstraksi jahe yang memberikan nilai total fenol tertinggi yaitu perlakuan blansir dengan air panas. Hasil rendemen tertinggi diperoleh pada proses pengekstraksian langsung (tanpa pemblansiran) dengan pengenceran 1:4. Penelitian sebelumnya memberikan perlakuan blansir dengan memanaskan jahe ke dalam air mendidih selama 3 menit. Uji coba proses tersebut pada peneitian memberikan nilai rendemen yang terendah $(47,80 \%)$ dibandingkan dengan perlakuan lainnya.

Perlakuan pemblansiran menggunakan air panas mampu meningkatkan nilai total fenol dibanding perlakuan lainya. Rimpang jahe segar setelah dicuci dan dibersihkan, disiram dengan air panas (suhu $90-95^{\circ} \mathrm{C}$ ) dan dibiarkan terendam dalam air panas tersebut selama 3 menit. Komponen fenolik pada jahe, yaitu gingerol diduga mengalami perubahan menjadi shagaol selama proses pemblansiran. Bhattarai et al. (2001) menyebutkan bahwa gingerol bersifat labil terhadap panas atau suhu tinggi, sehingga mudah terdehidrasi menjadi shagaol.

Proses pemblansiran dalam air panas/merebus jahejuga dapat meningkatkan konversi gingerol menjadi shagaol. Namun, pada proses perebusan dapat terjadi gelatinisasi pati jahe. Haq et al. (1986) menyebutkan bahwa jahe memiliki kandungan pati sejumlah 45,25\%. Nilai ini mencapai hampir $50 \%$ dari total bobot jahe. Menurut Ferry et al. (2006), pemanasan dispersi pati dalam air pada suhu $95^{\circ} \mathrm{C}$ selama 2,5 menit dapat menyebabkan gelatinisasi. Proses gelatinisasi menyebabkan peningkatan viskositas pada bahan (Fellow 2000). Gelatinisasi pati jahe teramati dari hasil panghancuran (parutan) jahe yang lebih liat dibandingkan dengan yang parutan jahe yang tidak diblansir 
dengan air mendidih. Adanya gelatinisasi menyebabkan penyerapan cairan dalam jahe serta komponen non-volatil jahe terperangkap dalan sel dan tidak bisa terekstrak. Struktur sel jahe menunjukkan bahwa granula pati berada struktur diluar dan menyelimuti sel penghasil minyak pada jahe, yang juga menghasilkan oleoresin(Ravindran et al. 2005).

Pemilihan jenis perlakuan pada proses ekstraksi jahe didasarkan pada peningkatan rendemen dengan tetap memberikan nilai fungsional yang tinggi (ditunjukkan dengan kadar total fenol). Optimasi dilakukan dengan pembobotan. Total fenol jahe ditetapkan memberikan nilai $60 \%$ dan rendemen memberikan nilai $40 \%$. Rendemen menjadi hal yang penting dalam meningkatkan efisiensi proses, akan tetapi karena minuman tradisional berbasis jahe lebih diunggulkan pada manfaat kesehatannya, sehingga komponen fenol lebih diprioritaskan. Tabel 3 berikut menunjukkan hasil pembobotan pada setiap perlakuan ekstraksi jahe.

Berdasarkan hasil perhitungan di atas, perlakuan ekstraksi jahe yang diblansir dengan air panas memiliki nilai tertinggi yaitu 5,1 dan berbeda nyata dibandingkan perlakuan lain pada taraf kepercayaan 95\%. Perlakuan ini dipilih sebagai perlakuan optimum karena memberikan total fenol $(2297,4$ ppm GAE) dan rendemen $(61,1 \%)$ lebih tinggi dan berbeda nyata dibandingkan perlakuan lainnya.

Total fenol pada jahe merupakan salah satu parameter fungsionalitas yang penting. Ekstrak jahe pada minuman memiliki kemampuan dalam stimulasi penyerapan glukosa (Diana 2010) dan memberikan kestabilan aktivitas antihiperglikemik dengan meningkatkan sensitivitas insulin (Indariani 2011). Peranan ekstrak jahe tersebut dipengaruhi oleh komponen fenolik ekstrak jahe. Senyawa penciri yang diduga sebagai senyawa aktif pada ekstrak jahe antara lain 6-gingerol, 8gingerol, 10-gingerol, dan 6-shagaol yang merupakan kelompok komponen fenolik (Indariani 2011).

\section{Ekstraksi Temulawak}

Proses ekstraksi temulawak dilakukan dengan prosedur yang sama seperti ekstraksi jahe. Tahapan ekstraksi terdiri atas pembersihan rimpang temulawak segar, pemblansiran, penghancuran, penyaringan, pengendapan, dan pasteurisasi. Herold (2005) dan Indariani (2011)menyatakan rendemen ekstraksi temulawak secara berurutan yaitu sebesar $49 \%$ dan $37,24 \%$. Terdapat tujuh perlakuan ekstraksi temulawak yang dilakukan pada penelitian ini. Parameter total fenol dan rendemen merupakan variabel yang diamati untuk setiap perlakuan. Gambar 4 menunjukkan perbedaan hasil total fenol dan rendemen pada berbagai perlakuan blansir temulawak.

Prosedur ekstraksi temulawak berdasarkan penelitian Febriani (2012) yang dilakukan dengan merebus temulawak tidak dapat menghasilkan ekstrak temulawak. Pengujian ekstraksi dilakukan dengan bobot awal bahan sejumlah 50-100 g. Temulawak yang telah diblansir dalam air yang dipanaskan cenderung menjadi liat ketika dihancurkan/diparut. Pemerasan tidak menghasilkan sari temulawak. Cairan yang keluar pada proses pemerasan berupa pati kental berwarna kuning yang merupakan suspensi pati temulawak. Spices Board (2002) menyatakan bahwa temulawak mengandung karbohidrat menjadi bagian yang dominan pada komposisi kimia temulawak, yaitu mencapai 69,9\%. Tidak adanya ekstrak yang dihasilkan, menyebabkan perlakuan ini dianggap gagal dan tidak dilakukan analisis total fenol. Bambirra et al. (2002) menyatakan bahwa pemasakan pada rimpang temulawak dapat menyebabkan galatinisasi pati. Hal ini juga dipengaruhi oleh struktur jaringan rimpang temulawak juga menunjukkan kelenjar penghasil cairan atau minyak pada temulawak dikelilingi oleh sel-sel yang 
mengandung banyak granula pati(Ravindran et al. 2007).

Optimasi proses ekstraksi temulawak, dilakukan melalui pembobotan terhadap nilai rendemen dan total fenol dari setiap

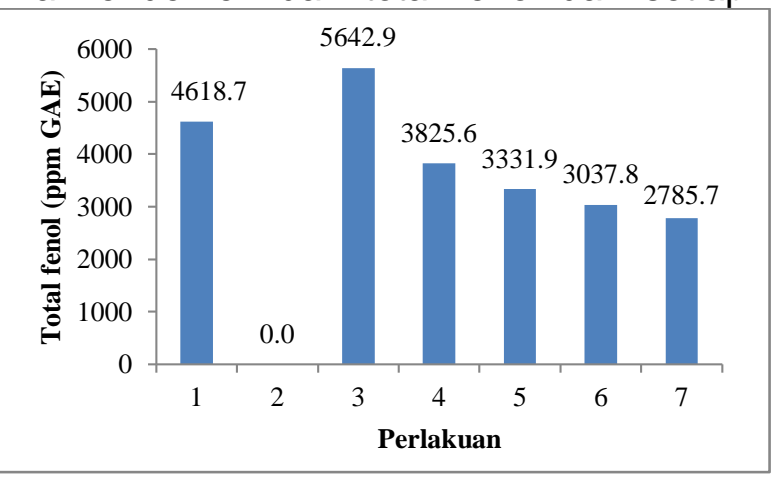

(a) perlakuan ekstraksi temulawak. Komponen fenol menyumbang nilai $60 \%$ dan rendemen

Keterangan:

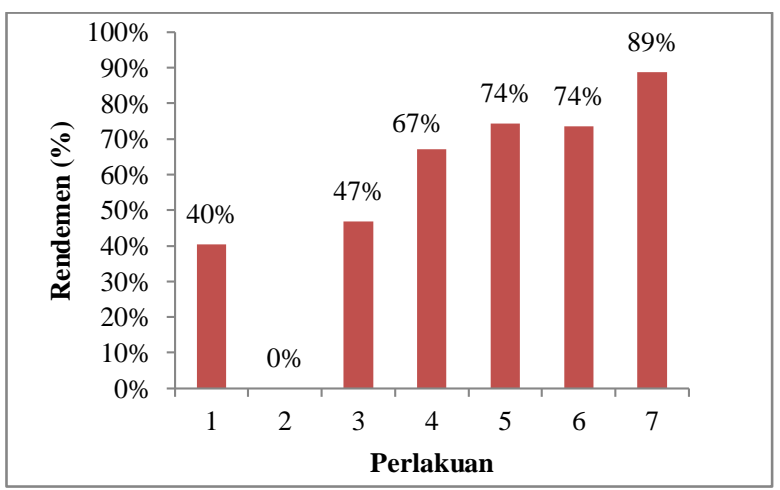

(b)

Perlakuan 1: diblansir dengan air panas

Perlakuan 2: diblansir dengan didihkan

Perlakuan 3: langsung diekstrak tanpa pengenceran

Perlakuan 4: langsung diekstrak dengan Pengenceran 1:1

Perlakuan 5: langsung diekstrak dengan Pengenceran 1:2

Perlakuan 6: langsung diekstrak dengan Pengenceran 1:3

Perlakuan 7: langsung diekstrak dengan Pengenceran 1:4

Gambar 4. Total fenol (a) dan rendemen (b) ekstrak temulawak pada berbagai perlakuan pemblansiran

Tabel 4. Hasil pembobotan total fenol dan rendemen pada berbagai perlakuan temulawak

\begin{tabular}{|c|c|c|c|c|c|}
\hline \multirow{2}{*}{ Perlakuan } & \multirow{2}{*}{ Total Fenol (ppm GAE) } & \multirow{2}{*}{$\begin{array}{l}\text { Rendemen } \\
(\%)\end{array}$} & \multicolumn{2}{|l|}{ Nilai } & \multirow{2}{*}{ Total } \\
\hline & & & Total Fenol & Rendemen & \\
\hline 1 & 4597,7 & $40,4 \%$ & 5 & 1 & $3,4^{b}$ \\
\hline 2 & - & $0,0 \%$ & - & - & - \\
\hline 3 & 5621,8 & $46,9 \%$ & 6,5 & 1,5 & $4,5^{\mathrm{a}}$ \\
\hline 4 & 3804,6 & $67,2 \%$ & 3,5 & 3,5 & $3,5^{b}$ \\
\hline 5 & 3310,9 & $74,3 \%$ & 2 & 4,5 & $3^{\mathrm{b}}$ \\
\hline 6 & 3016,8 & $73,5 \%$ & 1,5 & 4,5 & $2,7^{b}$ \\
\hline 7 & 2764,7 & $88,7 \%$ & 1,5 & 6,5 & $3,5^{\mathrm{b}}$ \\
\hline
\end{tabular}

Keterangan:

Huruf yang sama dalam satu kolom menyatakan tidak berbeda nyata pada taraf kepercayaan $95 \%$

Perlakuan 1: diblansir dengan air panas

Perlakuan 2: diblansir dengan didihkan

Perlakuan 3: langsung diekstrak tanpa pengenceran

Perlakuan 4: langsung diekstrak dengan Pengenceran 1:1

Perlakuan 5: langsung diekstrak dengan Pengenceran 1:2

Perlakuan 6: langsung diekstrak dengan Pengenceran 1:3

Perlakuan 7: langsung diekstrak dengan Pengenceran 1:4

40\%. Komponen fenol mendapat pembobotan lebih besar karena kesesuaian tujuan pembuatan minuman untuk mendapatkan produk dengan nilai fungsionalitas tinggi. Adapun hasil penilaian 
berbagai perlakuan blansir pada ekstraksi temulawak dapat dilihat pada Tabel 4.

Berdasarkan hasil penilaian di atas, perlakuan ekstraksi temulawak yang dipilih yaitu ekstraksi pada kondisi segar atau tanpa pemblansiran. Perlakuan 3 tersebut memiliki nilai akhir berdasarkan pembobotan sebesar 4,5 dan berbeda nyata dengan perlakuan lainnya pada taraf kepecayaan 95\%. Proses ekstraksi ini menghasilkan ekstrak temulawak dengan total fenol 5642.86 ppm GAE dan rendemen $46,9 \%$. Perlakuan panas (pemblansiran menggunakan air panas) menunjukkan penurunan total fenol dibandingkan ekstrak dari rimpang yang tidak diblansir. Hal ini berbeda pada hasil ekstraksi jahe yang menunjukkan peningkatan total fenol pada kondisi pemberian perlakuan panas. Hal itu disebabkan oleh adanya kerusakan komponen fenolik karena panas. Buescher \& Yang (2000) melaporkan bahwa jumlah komponen volatil dan warna pada temulawak cenderung tetap walaupun ekstraksi kurkumin pada temulawak mengalami penurunan karena adanya proses perebusan.

Temulawak merupakan komponen minor pada minuman fungsional ini. Persentase ekstrak temulawak dalam minuman hanya mencapai $2 \%(\mathrm{v} / \mathrm{v})$. Peran temulawak dalam minuman belum dipelajari secara spesifik. Indariani (2011) menyebutkan bahwa sebagai komponen tunggal dalam minuman, temulawak memiliki aktivitas antioksidan sejumlah 386,22 ppm AEAC. Optimasi formulasi minuman yang dilakukan Herold (2007) menunjukkan fenomena sinergis karena aktivitas antioksidan minuman formula optimal ini tidak lebih rendah daripada aktivitas antioksidan minuman komponen tunggalnya.

Komponen penting temulawak yang memberikan peran sebagai antioksidan yaitu kurkumin (Nahar \& Sarker 2005). Ravindran et al. (2007) menyatakan bahwa komponen biokimia pada temulawak terdiri atas tiga kelompok besar yaitu diphenilalkaloid, turunan phenil propone dari tipe asam sinama, serta terpenoid. Komponen utama temulawak, yaitu diphenilalkaloid lebih dikenal dengan istilah kurkumin. Diphenilheptanoid merupakan senyawa fenol dengan dua gugus fenil yang dihubungkan dengan C7 sebagai ikatan "punggung"-nya.

Ekstrak temulawak dalam produk minuman tradisional dimungkinkan mempunyai peranan dalam aktivitas antioksidan dan antihiperglikemik. Lebih lanjut dalam aplikasi produk minuman, Septiana et al. (2017) menyatakan bahwa minuman tradisional dengan ekstrak temualwak mengandung total fenol lebih tinggi daripada minuman lainnya. Hasil penelitian Indariani (2011) menunjukkan bahwa minuman dengan bahan temulawak memiliki aktivitas antihiperglikemik berupa stimulasi penyerapan glukosa, menekan kerusakaan lebih lanjut pada sel $\beta$ pada pulau Langerhans. Kurkuminoid dan sesquiterpenoid yang ada pada ekstrak C.logna dapat menurunkan kadar glukosa dalam tikus $\mathrm{KK}-\mathrm{A}(\mathrm{y})$ yang mengalami diabetes tipe 2 (Nishiyama et al. 2005). Penelitian yang dilakukan oleh Meghana (2007), menunjukkan bahwa kurkumin memiliki aktivitas melindungi sel $\beta$-pankreas terhadap kerusakan oksidatif akibat induksi streptozotocin.

\section{KESIMPULAN}

Penentuan waktu ekstraksi dan tahapan ekstraksi bahan minuman tradisional Indonesia dipilih berdasarkan rendemen serta aktivitas antioksidan dan total fenol tertinggi.Hasil optimasi proses ekstraksi pada masing-masing bahan minuman didapatkan:

1. Ekstraksi daun tanaman kumis kucing optimum pada kondisi pemanasan air pada suhu $\pm 95^{\circ} \mathrm{C}$ selama 30 menit dan didapatkan nilai aktivitas antioksidan 2508,9 ppm AEAC dan total fenol 926,6 ppm GAE

2. Ekstraksi kayu secang optimum pada kondisi pemanasan air pada suhu $\pm 95^{\circ} \mathrm{C}$ 
selama 30 menit dan didapatkan nilaiaktivitas antioksidan 1601,7 ppm AEAC dan total fenol 1319,9 ppm GAE.

3. Ekstraksi jahe optimum diperoleh melalui pemblansiran jahe dengan disiram dan direndam air panas $\left(90-95^{\circ} \mathrm{C}\right)$ selama 3 menit sebelum diparut dan diperasserta didapatkan total fenol 2294,6 ppm GAE dan rendemen ekstraksi sebesar $61,1 \%$

4. Ekstraksi temulawak optimum tanpa pemblansiran, langsung diparut dan diperas serta didapatkan total fenol ekstrak sejumlah 5621,8 ppm GAE dan rendemen sebesar $46,9 \%$.

\section{DAFTAR PUSTAKA}

Bettuzzi, S. 2009. Inhibition of human prostate cancer progression by administration of green tea cathecins: from the bench to the clinical trial. In: The 3rd world congress on tea and health nutraceutical \& pharmacuetical publications. ISANH. Dubai.

Bhattarai, S., Tran, V.H., Duke, C.C. 2001. The Stability of Gingerol and Shogaol in Aqueous Solutions. Journal of Pharmaceutical Science, 90(10), pp.1658-1664.

Bousetta, N., Vorobiev, E., Ress, T., De Ferron, A., Pecastaing, L., Ruscassie, R., Lanoiselle, J.L. 2012. Scale-up of high voltage electrical discharges for polyphenols extraction from grape pomace: Effect of the dynamic shock waves. Innovative Food Science and Emerging Technologies http://doi:10.1016/j.ifset.2012.05.004.

Buescher, R., Yang, L. 2000. Turmeric. In: Natural Food Colorants, Science and Technology. New York: Marcel Dekker.

Chanwitheesuk, A., Teerawutgulrag, A., Rakariyatham, N. 2005. Screeningof antioxidant activity and antioxidant compounds of some edible plants of Thailand. Food Chemistry, 92, pp. 491497.

Defang, L., Mingyang, G., Yonghe, H., Taihua, L., Jiao, Y., Yong, L., Mingdong, Y., Ming, Y., Jun, Z. dan Linglin, G. 2015. Effect of Sanhuangwuji powder, anti-rheumatic drugs, and ginger-partitioned acupoint stimulation on the treatment of rheumatoid arthritis with peptic ulcer: a randomized controlled study. Journal of Traditional Chinese Medicine. 35(3), pp.273-280.

Diana. 2010. Aktivitas Anti-hiperglikemik dari Minuman Fungsional Berbasis Kumis Kucing (Orthosiphon aristatus BI. Miq) Secara In Vivo dan Ex Vivo. Skripsi. Bogor: Program Sarjana Fakultas Teknologi Pertanian, Institut Pertanian Bogor.

Febriani, E. 2012. Peningkatan Citarasa Minuman Fungsional Berbasis Daun Kumis Kucing (Orthosiphon aristatus BI. Miq) berpemanis Non-Sukrosa Berdasarkan Optimasi pada Kombinasi Beberapa Varietas Jeruk.Skripsi. Bogor: Program Sarjana Fakultas Teknologi Pertanian, Institut Pertanian Bogor.

Fellow, P.J. 2000. Food Processing Technology: Principles and Practice. Ed ke-2. England: Woodhead Publishing Ltd.

Ferry, A., Hort, J., Mitchel, J.R., Cook, D., Lagarrigue, S., Pamies, B.V. 2006. Viscosity and flavour perception: Why is starch different from hydrocolloids?. Food Hydrocolloids, 20, pp.855-856.

Haq, F., Faraque, S.M., Islam, S., Ali, E. 1996. Studies of Zingiber officinale 
Roscoe. Part 1. Chemical investivigation of the rhizome. Bangladesh Journal of Scientific \& Industrial Research 21, (1-4), pp. 6169.

Herold.2007.Formulasi

Minuman

Fungsional Berbasis Kumis Kucing (Orthosiphon aristatus BI Miq) yang Didasarkan pada Optimasi Aktivitas Antioksidan, Mutu Citarasa, dan Warna. Skripsi. Bogor:Program Sarjana Fakultas Teknologi Pertanian, IPB.

Indariani, S. 2011. Aktivitas Antihiperglikemik Minuman Fungsional berbasis Ekstrak Daun Kumis Kucing (Orthosiphon aristatus BI. Miq) pada Mencit Hiperglikemik yang Diindukasi dengan Streptozotocin. Tesis. Bogor: Program Studi IImu Pangan Sekolah Pascasarjana, Institut Pertanian Bogor.

Hidalgo, G.I., Almajano, M.P. 2017. Red Fruits: Extraction of Antioxidants, Phenolic Content, and Radical Scavenging Determination: A Review. Antioxidants, 6, 7, pp.127.doi:10.3390/antiox6010007

Lafka, T.I., Sinanoglou, V., Lazosm, E.S. 2007. On the extraction andantioxidant activity of phenolic compounds from winery waste. Food Chemistry, 104 (3), pp. 1206-1214

Meghana, K., Senjeev, G., Ramesh, B. 2007. Curcumin prevents streptozotocin-induced islet damage by scavanging the radicals; A prophylactic and protective role. The European Journal of Pharmacology,577, pp.183191.
Molyneux, P. 2004. The use of the stable free radical diphenylpicryl-hydrazyl (DPPH) for estimating antioxidant activity. Journal of Science and Technology, 26 (2), pp.211-219.

Nahar, L., Sarker, S.D. 2005. Phytochemistry of the genus Curcuma. In: Ravindran PN, Nirmal Babu K, Sivaraman K. (Eds). Turmeric: The Genus Curcuma. Boca Raton: CRC Press.

Nishiyama, T., Mae, T., Kishida, H., Tsukagawa, M., Mimaki, Y., Kuroda, M., Sashida, Y., Takahashi, K., Kawada, T., Nakagawa, K., Kitahara, M. 2005. Curcuminoids and sesquiterpenoids in turmeric (Curcuma longa L.) suppress an increase in blood glucose level in type 2 diabetic KK-A(y) mice. Journal of Agriculture Food Chemistry, 53, pp.959-966.

Qu, W., Pan, Z., Ma, H. 2010. Extraction modeling and activities of antioxidants from pomegranate marc. Journal of Food Engineering, 99, pp.16-23.

Ravindran, P.N., Babu, K.N., Shiva, K.N. 2005. Botany and Crop Improvement of Ginger. In: Ravindran PN, Babu KN (ed). Ginger: The Genus Zingiber. Boca Raton: CRC Press.

Ravindran, P.N., Babu, K.N., Shiva, K.N. 2007. Botany and Crop Improvement of Turmeric. In: Ravindran PN, Babu KN, Sivaraman K (ed). Turmeric: The Genus Curcuma. Boca Raton: CRC Press

Septiana, A.T., Samsi, M., Mustaufik, M. 2017. Pengaruh Penambahan Rempah dan Bentuk Minuman terhadap Aktivitas 


\section{Antioksidan Berbagai Minuman Tradisional Indonesia. Agritech, 37(1),pp. 7-14, DOI: http://dx.doi.org/10.22146/agritech.1700 1}

Silva, E.M., Rogez, H., Larondelle, Y. 2007. Optimization of extraction of phenolics from Inga edulis leaves using response surface methodology. Separation and Purification Technology,55, pp. 381389.

Sithisarn, P., Jarikasem, S. 2010. Antioxidant Activity and Phenolic Content of Acanthopanax trifoliatus and Toddalia asiatica. Kasetsart. Journal of Natural Science, 44, pp. 234 - 242.

Spices Board. 2002. Quality Requirements of Spices for Export. Spices board. India.

Strycharz, S., Shetty, K. 2002. Effect of Agrobacterium rhizogenes on phenolic content of Menthapulegium alite clonal line for phytomedition applications. Journal of Process Biochemistry, 38, pp.287-293.

Suratno, Y.D., Palupi, N.S., Astawan, M. 2014. Pola konsumsi pangan fungsional dan formulasi minuman fungsional instan berbasis antioksidan. Jurnal Mutu Pangan 1(1):56-64. ISSN 2355-5017.
Takamatsu, S., Hodges, T.W., Rajbhandari, I., Gerwick,W.H., Hamann, M.T., Nagle, D.G. 2003. Marine natural products as novel antioxidant prototypes. Journal of Natural Products.66: 605-608.

Rekasih,M. 2016. Aktivitas Antihiperglikemik Minuman Effervescent Nanoenkapsulasi Berbasis Ekstrak Daun Kumis Kucing (Othosiphon Aristatus B1. Miq) Pada Tikus Diabetes Yang Diinduksi Streptozotocin Tesis. Bogor: Program Studi IImu Pangan Sekolah Pascasarjana, Institut Pertanian Bogor.

Veljović, M., Kalušević, A., Salević, A., StamenkovićĐoković, M., Vukosavljević, P., Bugarski, B., Nedović, V. 2015.Optimization of herbs extraction for soft drink production. In: The 6th International Scientific Agricultural Symposium "Agrosym 2015" Book of Proceedings, Bosnia and Herzegovina, Jahorina, p. 478-483.

Vernin, G., Parkanyi, C. 2005. Chemistry of Ginger. In: Ravindran PN, Babu KN (ed). Ginger: The Genus Zingiber. Boca Raton: CRC Press.

Wijaya, C.H., Rahminiwati, M., Wu, M.C,. Lo, D. 2011. Inhibition of $\alpha$-amylase activities of some Indonesian herbs: in vitro study. In: The $12^{\text {th }}$ ASEAN Food Conference. Bangkok. 